\title{
Effect of Water Depth on Seasonal Variation in the Chemical Composition of Akamoku, Sargassum horneri (Turner) C. Agardh
}

\author{
Kaori Murakamii', Yoko Yamaguchi' ${ }^{2}$, Yohko Sugawa-Katayama ${ }^{3}$, Masayuki Katayama ${ }^{3}$ \\ ${ }^{1}$ Department of Food Sciences and Biotechnology, Faculty of Life Sciences, Hiroshima Institute of Technology, \\ Hiroshima, Japan \\ ${ }^{2}$ Department of Environmental Science, Faculty of International College of Arts and Sciences, Fukuoka \\ Women's University, Fukuoka, Japan \\ ${ }^{3}$ Department of Health and Nutrition, Osaka Aoyama University, Osaka, Japan \\ Email: k.murakami.tf@it-hiroshima.ac.jp, youko@fwu.ac.jp, katayama@osaka-aoyama.ac.jp, \\ mykataym@zeus.eonet.ne.jp
}

Received 18 February 2016; accepted 15 April 2016; published 18 April 2016

Copyright () 2016 by authors and Scientific Research Publishing Inc.

This work is licensed under the Creative Commons Attribution International License (CC BY).

http://creativecommons.org/licenses/by/4.0/

(c) (i) Open Access

\section{Abstract}

The brown alga, Akamoku, also known as Sargassum horneri, was harvested at depths of 1 - 2 and $5 \mathbf{~} \mathbf{m}$ in the oceanic areas of the Chikuzen Sea off the coast of Fukuoka, Japan, and its chemical composition (moisture, protein, lipid, ash, carbohydrate and total dietary fiber content) was investigated. The aim of this study was to elucidate the relationship between the chemical components and the growth of $S$. horneri as recyclable resource for a sustainable future. $S$. horneri at an ocean depth of $5 \mathrm{~m}$ grew rapidly. The biomass was abundant from January until April. After maturation and gamete release at the middle of April, plant senescence began occurring, and only short plants remained at the sea bottom. On the other hand, $S$. horneri at an ocean depth of $1-2 \mathrm{~m}$ grew slowly and could be harvested until early June. The protein, lipid and total dietary fiber content of $S$. horneri at an ocean depth of $5 \mathrm{~m}$ showed apparent gender-based differences.

\section{Keywords}

Seaweed, Chemical Composition, Total Dietary Fiber, Seasonal Variation, Sargassum horneri

\section{Introduction}

Seaweed contains mucilage polysaccharides such as agar, alginate and carrageenan. These phycocolloids have

How to cite this paper: Murakami, K., Yamaguchi, Y., Sugawa-Katayama, Y. and Katayama, M. (2016) Effect of Water Depth on Seasonal Variation in the Chemical Composition of Akamoku, Sargassum horneri (Turner) C. Agardh. Natural Resources, 7, 147-156. http://dx.doi.org/10.4236/nr.2016.74015 
been used as gelling agents and emulsifiers in the food and pharmaceutical industries [1]. Brown alga polysaccharides exhibit antitumor and antiviral activity [2] [3]. Additional brown alga components have also been reported to possess additional physiological activities, including prevention of blood coagulation; leukotrienemediated chloride absorption; regulation of bone metabolism; and effects on ingestion and excretion of cholesterol [4]-[8].

Thus, the demand for seaweed as a source of foods and biochemicals is expected to increase in the future. However, a limited number of seaweed species are available for practical use. One of the remaining unexplored seaweed species is Sargassum horneri, a brown alga growing in the coastal sea.

We reported on the seasonal changes in the chemical composition of moisture, protein, lipid, ash, carbohydrate, total dietary fiber (TDF), calcium, magnesium and zinc contents of S. horneri [9]. We have also reported on the changes in the general components after the parboiling process of $S$. horneri harvested from the Chikuzen Sea. We revealed that the chemical composition of $S$. horneri varied with its growth and maturity. An increase in TDF was observed after the appearance of receptacles, which appeared to correspond to the highest maturity, suggested by an increasing amount of fucoidan content and viscous exudates from the tissues of S. horneri. S. horneri is rich in dietary fiber and minerals, and can be developed for human consumption. The optimum season to harvest alga for human consumption may be early spring, when its growth and maturity are complete, and its dietary fiber and mineral contents have reached their maximum values.

On the other hand, S. horneri is a component of Sargassum beds, which are an important nursery ground for living marine organisms, such as fishes, crabs, sea urchins, abalones and so on. Sargassum beds perform the role of water quality purification and the prevention of red tide buildup [10] [11]. Seaweed species show great variation in their nutrient content in relation to various environmental factors, and most environmental parameters display seasonal variation [12] [13].

For its practical use as an edible resource, information on the influence of growing depth on the nutritional components and the seasonal variations of $S$. horneri in relation to its growth and maturity is important. In particular, S. horneri is a component of Sargassum beds, which also play important roles in resource enhancement of the coastal fisheries. In order to maintain the balance of the marine biomass and for its use as an edible resource, it is useful to understand the growth and maturity of $S$. horneri, and the relation to its nutritional value.

In addition, seaweed has recently been identified as a potential alternative source of renewable biofuel production [14]-[16]. S. horneri, which grows rapidly for a short period of time, may be a suitable material for biofuel. It is important to understand the relationship between the algal life cycle and chemical constitution such as carbohydrate content in S. horneri.

In the present study, seasonal changes in the chemical compositions with regard to moisture, protein, lipid, ash, carbohydrate and TDF content of S. horneri harvested in Chikuzen Sea at ocean depths of $1-2$ and $5 \mathrm{~m}$ were investigated to elucidate the influence of growth at a certain ocean depth on the chemical components of $S$. horneri in relation to its growth and maturity.

\section{Materials and Methods}

\subsection{Sampling of the Seaweed}

Samples of the seaweed S. horneri were collected once per month from November 2005 to June 2006 in the Chikuzen Sea, off the coast of the Fukuoka prefecture, Japan. Sampling was carried out at a depth of 1 - 2 and 5 $m$ in ocean areas near Nagasakibana, Oshima, Munakata City. The seaweed harvested from December 2005 was used for chemical component analysis. In addition, respective branches of male and female plants were analyzed from January, when their gender differences were most discernible. The harvested plants were cleaned and washed with distilled water to remove epiphytes and encrusting materials; their lengths and weights were subsequently measured after blotting out any excess water. The upper two-thirds of the full length of the plants were used as the edible portions, and the bottom one-third rigid portions were discarded. Seasonal changes in the chemical composition of the edible portions were determined. After $0.5-2 \mathrm{~kg}$ of edible portions from a number of seaweed plant were lyophilized, the dried samples were pulverized in a coffee mill and pooled. The homogenized samples were stored in polyethylene bottles at $-30^{\circ} \mathrm{C}$ until further analysis.

\subsection{Maturity Index}

Judgment of concerning gender differences was made on the basis of the receptacles of the alga, and the maturi- 
ty index was expressed as the ratio of the number of plants with discernible gender differences distinction to the total number of plants.

\subsection{Analytical Methods}

Moisture, protein, lipid, ash, carbohydrate and TDF contents were determined using standard AOAC methods [17]-[22]. The homogenized samples consisted of the edible portion of S. horneri (0.5 - $2 \mathrm{~kg}$ of S. horneri; 4 - 12 plants). Moisture, protein, lipid, ash and TDF were measured using methods described by Murakami et al. [9].

Carbohydrate contents were calculated as weight differences between the total weight and the sum of the amounts of moisture, protein, lipid and ash contents.

\subsection{Statistical Analysis}

Results are expressed either as mean values or as mean values \pm standard deviation. The Student's $t$-test was used to determine statistical differences in the lengths and weights measured for each depth group. The Wilcoxon-Mann-Whitney test was used to compare the chemical composition of dry-weight samples of two depth groups. Differences with $p$ values $<0.05$ were considered statistically significant. Statistical analyses were performed using Kaleida Graph ver. 3.6 (Synergy Software; HULINKS, Tokyo, Japan) on Windows 7 (Microsoft, Tokyo, Japan).

\section{Results}

\subsection{Seasonal Changes of Biomass}

Data on the biomass are shown in Table 1 and Figure 1. In the middle of November, the mean length of the plants was $14.8 \pm 3.2 \mathrm{~cm}$ at $1-2 \mathrm{~m}$ ocean depth, and $71.1 \pm 31.1 \mathrm{~cm}$ at $5 \mathrm{~m}$ ocean depth. The mean length of the plants increased to a maximum value of $8.97 \pm 1.88 \mathrm{~m}$ by the middle of January at $5 \mathrm{~m}$ ocean depth, and $1.81 \pm$ $0.08 \mathrm{~m}$ by the middle of February at a $1-2 \mathrm{~m}$ ocean depth (Figure 1). The maximum plant lengths were $12.7 \mathrm{~m}$ at $5 \mathrm{~m}$ ocean depth, and $6.5 \mathrm{~m}$ at $1-2 \mathrm{~m}$ ocean depth (Table 1). The mean weight of the plants increased to a maximum value of $16.6 \pm 0.82 \mathrm{~kg}$ by the middle of March at $5 \mathrm{~m}$ ocean depth, and to $3.96 \pm 1.65 \mathrm{~kg}$ by the middle of February at $1-2 \mathrm{~m}$ ocean depth (Figure 1). The maximum plants weight was $28.7 \mathrm{~kg}$ at $5 \mathrm{~m}$ ocean depth and $0.63 \mathrm{~kg}$ at $1-2 \mathrm{~m}$ ocean depth (Table 1). During the study period, the mean length and weight of plants harvested at $5 \mathrm{~m}$ ocean depth were significantly greater than those of plants harvested at $1-2 \mathrm{~m}$ ocean depth ( $p$ $<0.0001$; Table 1). Both mean length and weight of the plants increase earlier and to a greater length at $5 \mathrm{~m}$ than 1 - 2 m ocean depth (Figure 1). As $S$. horneri age, they are torn to pieces or separated from rocks in the sea, resulting in their drift depositions into the sea. $S$. horneri flowed out at $5 \mathrm{~m}$ ocean depth from the middle April. On the other hand, $S$. horneri were harvested until the middle of June at $1-2 \mathrm{~m}$ in ocean depth.

The gender differences became discernible after the middle of January (5 m ocean depth, 80\%; 1 - $2 \mathrm{~m}$ ocean depth, $5 \%$ ). Male and female receptacles were clearly discernible by the middle of March (5 m ocean depth) and April (1 - 2 m ocean depth; Figure 1).

The chemical composition of S. horneri was measured using samples collected from December 2005. After the middle of January 2006, the gender differences became clearer, so the chemical compositions of the male and female plants could be separately determined.

\subsection{Seasonal Changes in Chemical Components}

Seasonal changes in chemical components were apparent on a wet- weight basis for evaluation of brown algae as a food resource (Figure 2). The dry-weight basis for evaluating $S$. horneri as a biofuel was moisture content, deduced from sample weight. The dry-weight basis is calculated by subtracting the moisture content from the wet-weight basis. The chemical compositions of $S$. horneri harvested at an ocean depth of 1 - $2 \mathrm{~m}$ (from December 16, 2005, to June 5, 2006) and 5 m (from December 16, 2005, to April 17, 2006) are shown in Table 2.

\subsubsection{Moisture Contents}

The moisture contents of S. horneri are shown in Figure 2 and Table 2. The primary component of $S$. horneri throughout the season is moisture (approximately 90\%). According to the wet-weight basis, gender differences 


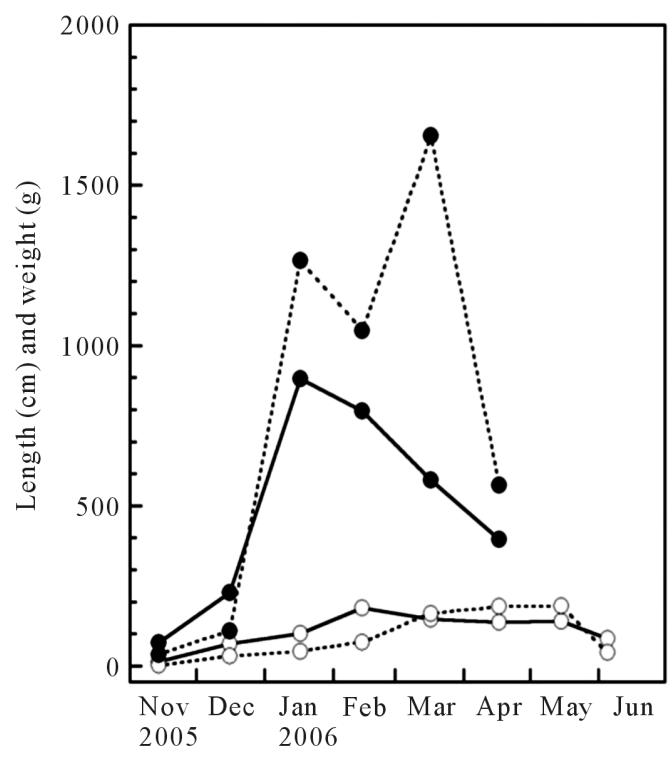

(a)

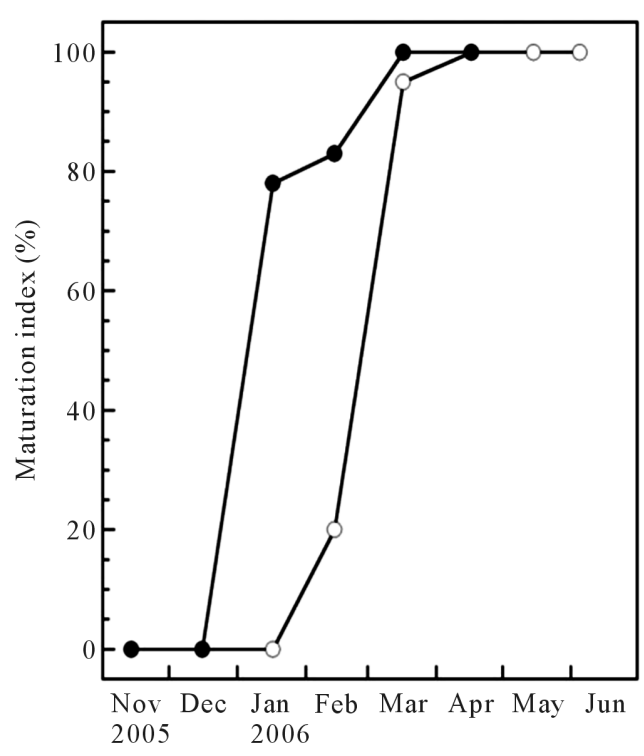

(b)

Figure 1. Seasonal changes in plant length, weight and maturity index of Sargassum horneri. Plants of $S$. horneri were harvested from Chikuzen Sea, Fukuoka prefecture, and their length and wet weight were measured. Nine to 66 plants were harvested from November 14, 2005, to June 5, 2006. The results are presented as mean values. Maturity index was expressed as the ratio of the number of plants with discernible gender distinction to the total number of plant. ०: Ocean depth of 1 - 2 m; •: Ocean depth of $5 \mathrm{~m}$; —: Length or maturation index, …... Weight.

Table 1. Effect of depth on plant length and wet-weight of Sargassum horneri.

\begin{tabular}{|c|c|c|c|c|c|c|}
\hline & \multicolumn{3}{|c|}{ Length (cm) } & \multicolumn{3}{|c|}{ Weight (g) } \\
\hline & Mean \pm SD & & Range & Mean \pm SD & & Range \\
\hline Ocean depth of 1 - 2 m $(n=250)$ & $89.0 \pm 90.5$ & * & $8.0-652$ & $75.8 \pm 108.5$ & * & $0.7-627$ \\
\hline Ocean depth of $5 \mathrm{~m}(n=93)$ & $389 \pm 318$ & & $11.0-1270$ & $546 \pm 697$ & & $2.1-2874$ \\
\hline
\end{tabular}

Plants of S. horneri were harvested at the ocean depth of 1 - 2 m (from November 14, 2005, to June 5, 2006) and 5 m (from November 14, 2005, to April 17, 2006) of Chikuzen Sea, Fukuoka prefecture and their length and wet weight were measured. " $n$ " is the number of sample plants. $t$-test; ${ }^{*} p<$ 0.0001 .

Table 2. Chemical composition of Sargassum horneri on dry-weight basis.

\begin{tabular}{|c|c|c|c|c|}
\hline & \multicolumn{2}{|c|}{ Ocean depth of 1 - $2 \mathrm{~m}(n=13)$} & \multicolumn{2}{|c|}{ Ocean depth of $5 \mathrm{~m}(n=11)$} \\
\hline & Mean \pm SD & Range & Mean \pm SD & Range \\
\hline Moisture (\%) & $88.1 \pm 1.3^{*}$ & $86.2-90.3$ & $90.6 \pm 1.3^{*}$ & $88.6-93.4$ \\
\hline Protein (mg/g dry) & $93.5 \pm 38.9$ & $52.4-195$ & $101 \pm 32$ & $59.4-150$ \\
\hline Lipid (mg/g dry) & $4.03 \pm 0.51^{* *}$ & $2.98-4.99$ & $5.64 \pm 1.97^{* *}$ & $2.64-8.59$ \\
\hline Ash (mg/g dry) & $258 \pm 26$ & $222-312$ & $277 \pm 27$ & $228-311$ \\
\hline Carbohydrate (mg/g dry) & $645 \pm 48$ & $533-695$ & $617 \pm 50$ & $555-692$ \\
\hline TDF (mg/g dry) & $477 \pm 63^{* * *}$ & $390-589$ & $409 \pm 56^{* * *}$ & $321-495$ \\
\hline
\end{tabular}

The dry weight was obtained by dehydration as described in the preceding legend. The chemical composition of $S$. horneri harvested at the ocean depth of 1 - 2 m (from December, 16, 2005, to June 5, 2006) and 5 m (from December, 16 2005, to April 17, 2006) were averaged. TDF: total dietary fiber. Wilcoxon-Mann-Whitney test; ${ }^{*} p<0.001,{ }^{* *} p<0.05,{ }^{* * *} p<0.02$. 


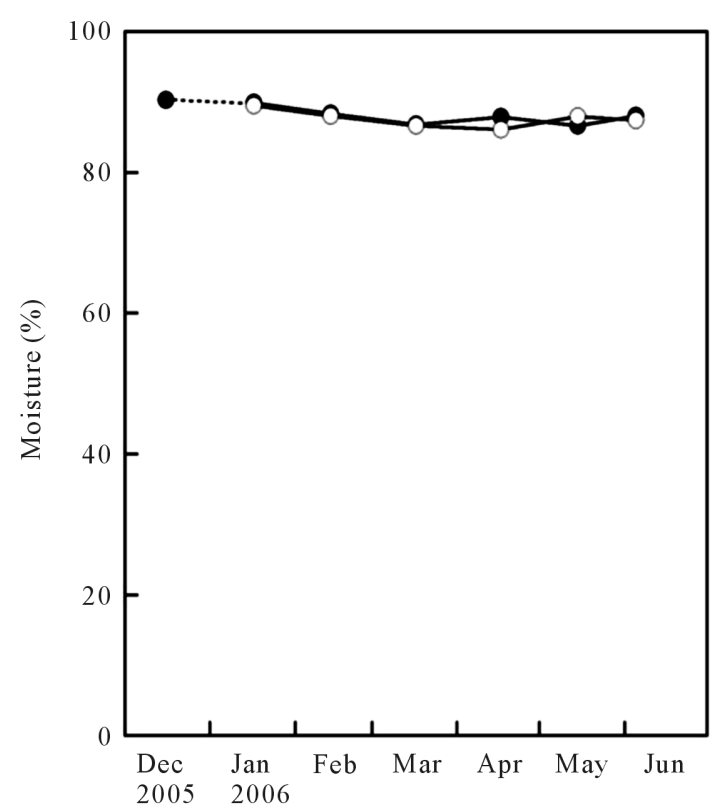

(a)

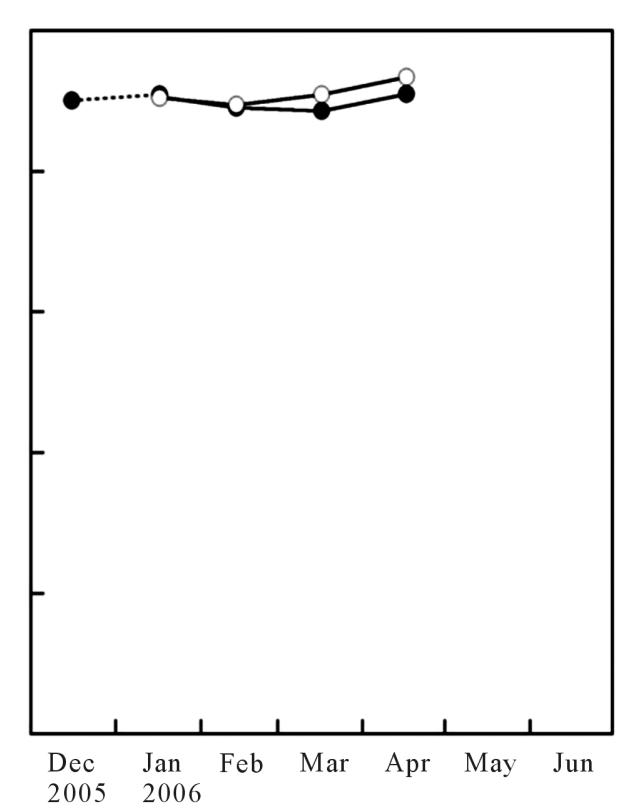

(b)

Figure 2. Seasonal variations in the moisture contents on the wet weight basis of Sargassum horneri. The moisture contents in the samples harvested from December 16, 2005, to June 5, 2006, were determined. Mean values are calculate from 2 specimens from homogenized sample $(0.4-1.9 \mathrm{~kg}$ of edible portions). The gender differences were distinctly observed after the end of January. (a) Ocean depth of 1

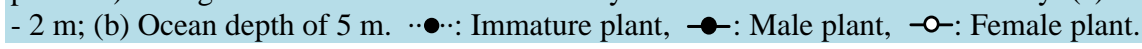

were not significant (Figure 2). However, the mean moisture contents for plants harvested at $5 \mathrm{~m}$ ocean depth $(90.6 \% \pm 1.3 \%)$ was higher than that for plants harvested at 1 - 2 m ocean depth (88.1 $\pm 1.3 \%$; Table 2$)$.

\subsubsection{Protein Contents}

The seasonal changes in protein contents of $S$. horneri are shown in Figure 3. The maximum protein content was $19.0 \mathrm{mg} / \mathrm{g}$ at an ocean depth of $1-2 \mathrm{~m}$, and $14.8 \mathrm{mg} / \mathrm{g}$ at an ocean depth of $5 \mathrm{~m}$ on wet-weight basis in December, with a tendency to decrease throughout the remainder of the study period. The protein content in the plant at an ocean depth of $1-2 \mathrm{~m}$ increased in March. On the other hand, gender differences regarding protein content in the plant at an ocean depth of $5 \mathrm{~m}$ were observed. The protein content of male plants increased in March $(11.7 \mathrm{mg} / \mathrm{g})$, while the protein content of the female plants did not show a tendency to decrease in January and February (11.0 and $10.6 \mathrm{mg} / \mathrm{g}$, respectively).

\subsubsection{Lipid Contents}

The seasonal changes in lipid contents of $S$. horneri are shown in Figure 4. The lipid contents $(0.3-0.8 \mathrm{mg} / \mathrm{g})$ of $S$. horneri showed the lowest value among all chemical constituents. When harvested at an ocean depth of 1 $2 \mathrm{~m}$, the maximum lipid content in female plants was observed in April $(0.61 \mathrm{mg} / \mathrm{g})$; while the maximum lipid content in male plants was observed in May $(0.65 \mathrm{mg} / \mathrm{g})$. When harvested at an ocean depth of $5 \mathrm{~m}$, the maximum lipid content in female plants was observed in February $(0.57 \mathrm{mg} / \mathrm{g})$, while the maximum lipid content in male plants was observed in March (0.79 mg/g; Figure 4).

The mean lipid contents on a dry-weight basis were significantly higher for plants harvested at a $5 \mathrm{~m}$ ocean depth $(5.64 \pm 1.97 \mathrm{mg} / \mathrm{g})$ than for those harvested at 1 - 2 m ocean depth $(4.03 \pm 0.51 \mathrm{mg} / \mathrm{g} ; p<0.05$; Table 2).

\subsubsection{Ash Contents}

The seasonal changes in ash contents of $S$. horneri are shown in Figure 5. The ash contents were in the range of $26.0-37.5 \mathrm{mg} / \mathrm{g}$ on a wet-weight basis, were not much less varied throughout the season, although some gender differences were observed between February and April. When harvested at an ocean depth of $5 \mathrm{~m}$, the ash content of the male plants (30.7 mg/g) was higher than that of the female plants $(22.6 \mathrm{mg} / \mathrm{g})$ in April. 


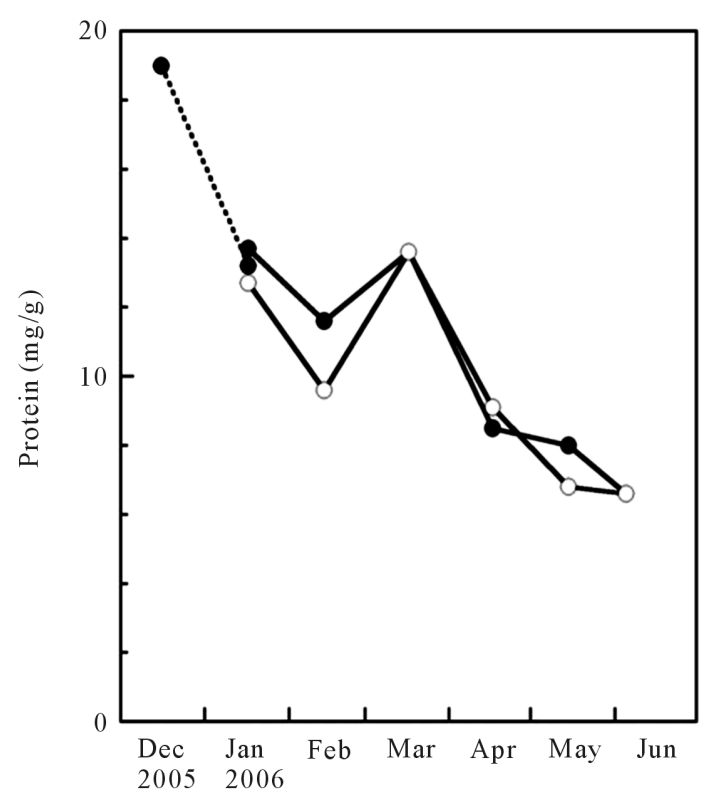

(a)

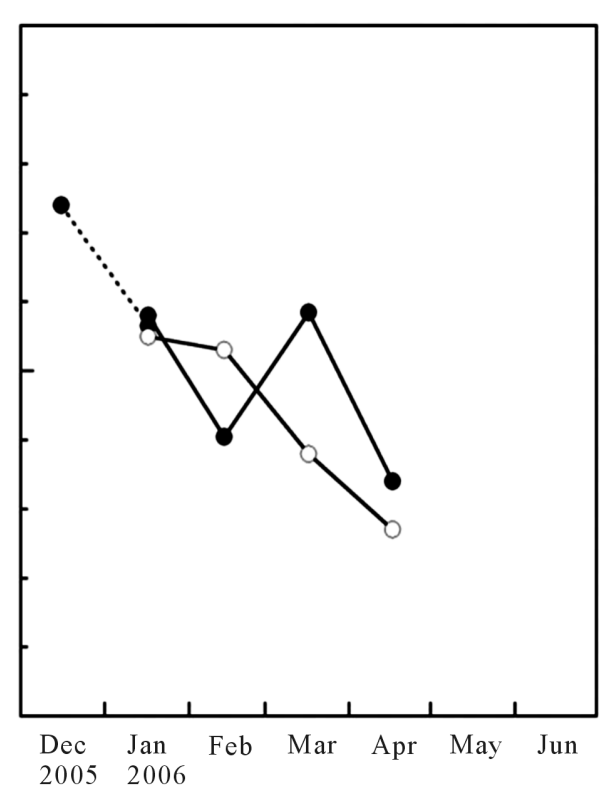

(b)

Figure 3. Seasonal variations in the protein contents on the wet weight basis of Sargassum horneri. The same homogenized samples as used for Figure 2.

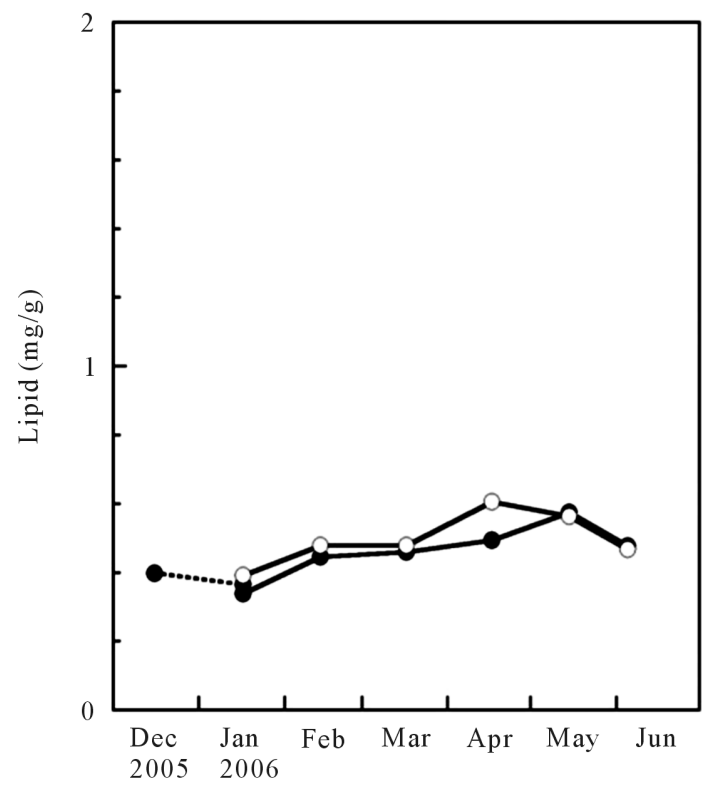

(a)

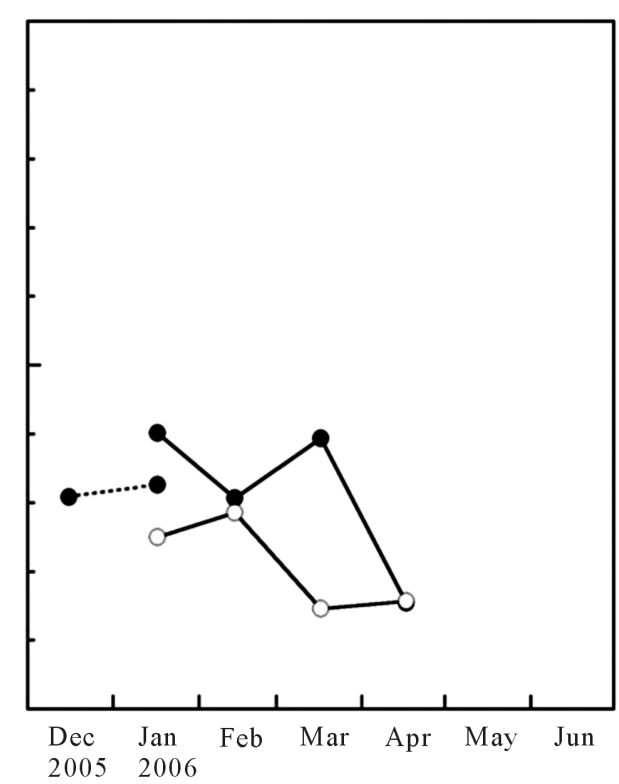

(b)

Figure 4. Seasonal variations in the lipid contents on the wet weight basis of Sargassum horneri. The same homogenized samples as used for Figure 2.

\subsubsection{Carbohydrate Contents}

The seasonal changes in carbohydrate contents of S. horneri are shown in Figure 6. The carbohydrate contents were calculated as the differences between the total weight and the sum total of the moisture, protein, lipid and ash contents. The carbohydrate contents of plants at an ocean depth of $1 \mathrm{~m}$ increased gradually until April (female, $98.3 \mathrm{mg} / \mathrm{g}$ ) or May (male, $90.2 \mathrm{mg} / \mathrm{g}$ ). When harvested at an ocean depth of $5 \mathrm{~m}$, the maximum carbohydrate contents of the plants were observed in February $(68.8 \mathrm{mg} / \mathrm{g}$ and $75.8 \mathrm{mg} / \mathrm{g}$ for female and male, respectively). 


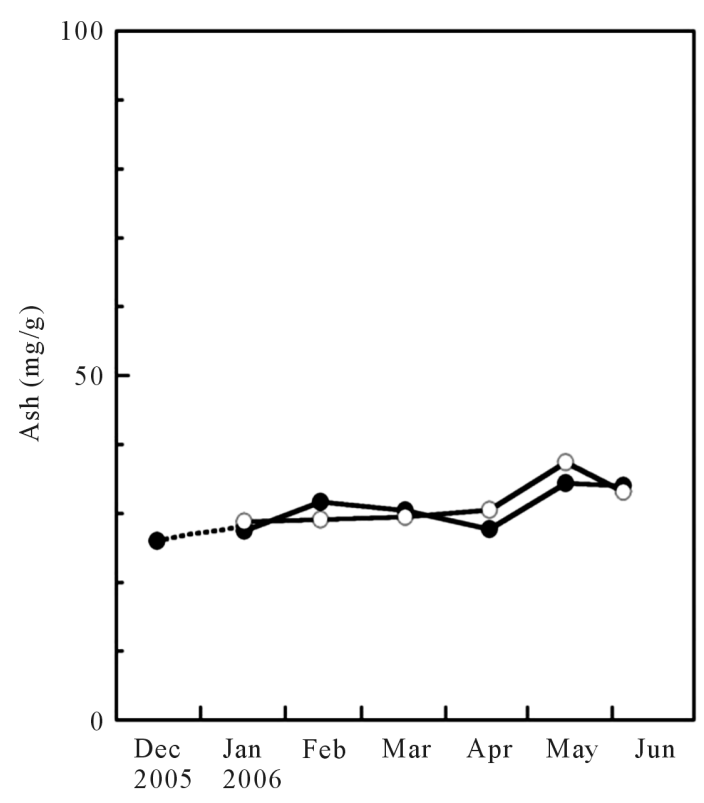

(a)

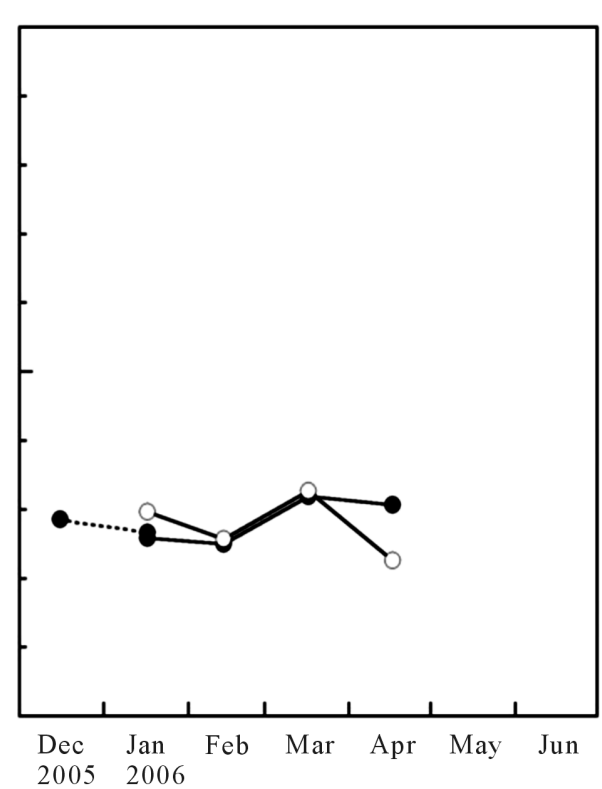

(b)

Figure 5. Seasonal variations in the ash contents on the wet weight basis of Sargassum horneri. The same homogenized samples as used for Figure 2.

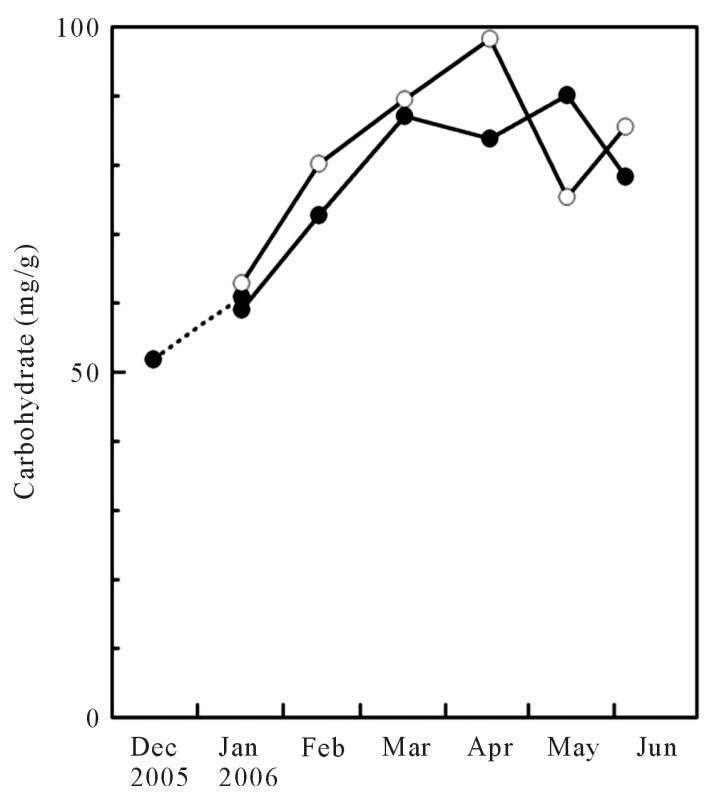

(a)

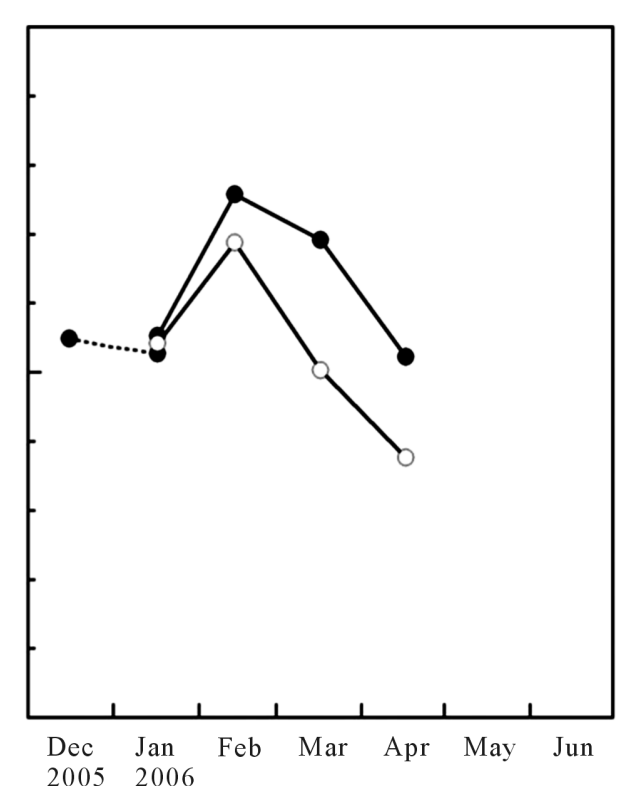

(b)

Figure 6. Seasonal variations in the carbohydrate contents on the wet weight basis of Sargassum horneri. The same homogenized samples as used for Figure 2. Carbohydrate contents were calculated as differences between the total weight and the sum of the moisture, protein, lipid and ash contents.

\subsubsection{Total Dietary Fiber Contents}

Seasonal changes in TDF contents of $S$. horneri are shown in Figure 7. The TDF content of plants at an ocean depth of $1 \mathrm{~m}$ increased gradually until June $(74.2 \mathrm{mg} / \mathrm{g}$ and $69.0 \mathrm{mg} / \mathrm{g}$ for female and male, respectively). When harvested at an ocean depth of $5 \mathrm{~m}$, the maximum carbohydrate content of the plants was observed in February (43.9 mg/g and $54.2 \mathrm{mg} / \mathrm{g}$ for female and male, respectively). It was apparent that an increase in TDF content from February corresponded to plant maturity (Figure 1). 


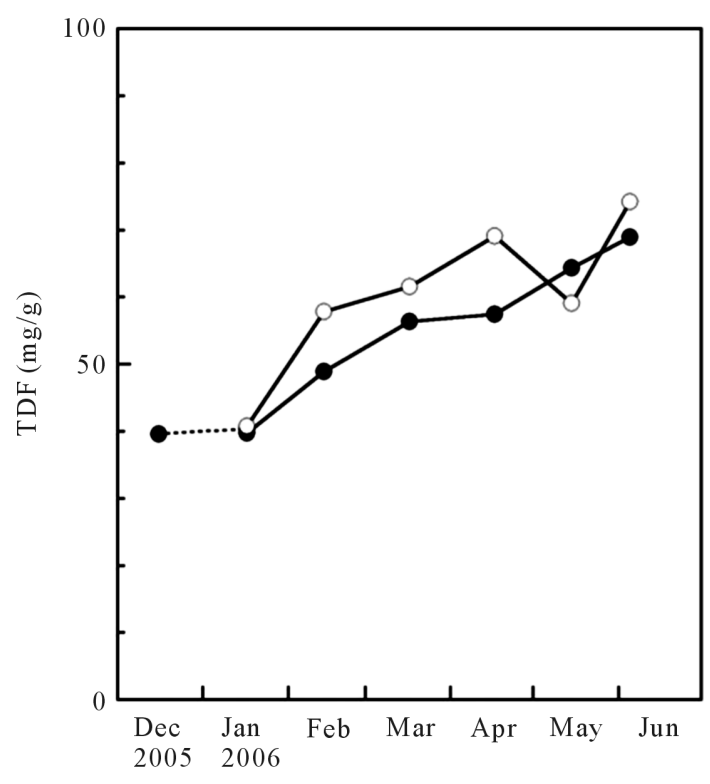

(a)

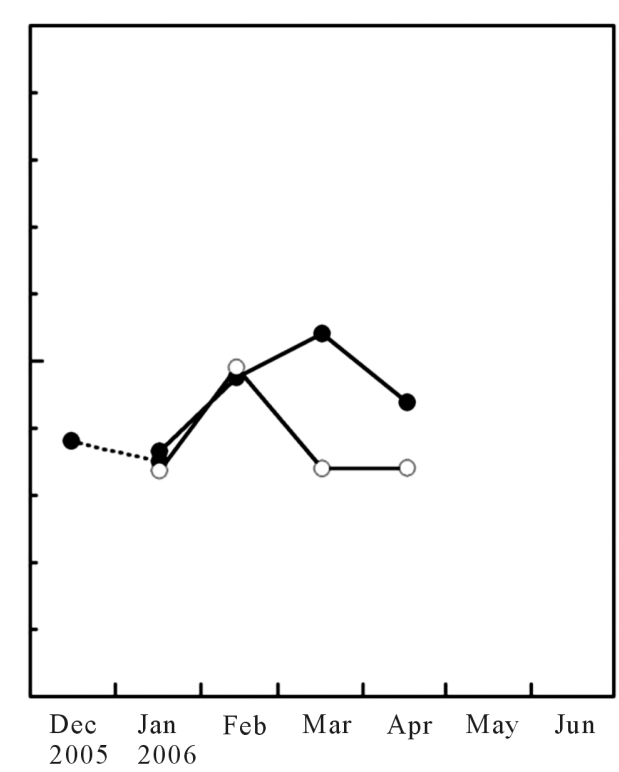

(b)

Figure 7. Seasonal variations in the total dietary fiber contents on the wet weight basis of Sargassum horneri. The same homogenized samples as used for Figure 2. TDF: total dietary fiber.

The mean TDF content on a dry-weight basis was higher for plants harvested at a $5 \mathrm{~m}$ ocean-depth $(477 \pm 63$ $\mathrm{mg} / \mathrm{g}$ ) than for those harvested at a 1 - 2 m ocean-depth (409 $\pm 56 \mathrm{mg} / \mathrm{g} ; p<0.02$; Table 2).

\section{Discussion}

The results of this study show that the chemical compositions of $S$. horneri harvested from the Chikuzen Sea changed according to the growth and maturity of the plant. To our knowledge, this study is first to demonstrate the effect of seasonal variation on the chemical composition of $S$. horneri according to differences in water depth and gender. In order for the use of $S$. horneri as an edible resource to proceed practically, it is important to retrieve basic information on the relationship and the seasonal variation of the growth and maturity of the plant, as well as its nutritional content. In particular, S. horneri is a component of Sargassum beds, which play important roles in resource enhancement of coastal fisheries. To maintain the balance of the marine biomass [10], it is important to understand the process of growth and maturity of S. horneri, as well as its relationship with nutrition, for the use of this plant as an edible resource. In addition, these data can assist in determining at which stage of life the plant contains the highest levels of carbohydrates, and thereby assist in the application of $S$. horneri as a resource of biofuels.

S. horneri grows more rapidly in deep water (i.e., an ocean depth of $5 \mathrm{~m}$ ) than in shallow water (i.e., an ocean depth of $1-2 \mathrm{~m}$ ). S. horneri in shallow water may be harvested even after the seaweed in the deep water has flowed out. Moreover, $S$. horneri harvested at an ocean depth of $5 \mathrm{~m}$ from February to March, or at an ocean depth of $1-2 \mathrm{~m}$ from April to June was the most suitable as food nutritionally. At these times, $S$. horneri achieves its maximum length and weight, and the carbohydrate and TDF contents reach their respective peak values. Moreover, $S$. horneri forms receptacles during these periods.

The protein content was observed to increase, depending on gender and ocean depth, which appears to be related to the plant's maturity (Figure 3): at a depth of $1-2 \mathrm{~m}$ in March (both genders), and at a depth of $5 \mathrm{~m}$ in February (female) or March (male). These observations were supported by the results of a recent study of $S$. horneri that was harvested at an ocean depth of $3 \mathrm{~m}$ (Murakami et al., 2011). We surmise that protein synthesis may be required for plant maturity.

The lipid content of female plants achieved its maximum levels earlier than that of male plant, both at ocean depths of $1-2 \mathrm{~m}$ and $5 \mathrm{~m}$. Furthermore, the protein and TDF contents of female plant harvested at an ocean depth of $5 \mathrm{~m}$, achieved their maximum value earlier than those of male plants harvested at the same depth did (February and March, respectively). 
The carbohydrate and TDF contents also increased, and correlated with the growth curve and the maturity of plants. These changes appear to be related to the amount of viscous exudate of $S$. horneri (data not shown).

$S$. horneri shreds and flows out subsequently, when going to aging. The seaweed that drifts ashore eventually decomposes causing several aesthetic and environmental problems, including an unsightly appearance and foul odor from decomposition by microorganisms, respectively. It often causes unsightly appearance and foul odor from decomposition by microorganisms. To alleviate these problems, we are investigating the possibility of utilizing $S$. horneri as a recyclable resource for sustainable edible and biofuel consumption by using the information that we generate throughout the plant's lifecycle. Specifically, S. horneri may be used as a biofuel before flowing out or after drifting ashore. Therefore, it is more advisable to harvest the upper half or third of the plant than to harvest the whole plant from the point of the Sargassum bed retention.

$S$. horneri can be used as an edible resource for extended periods, with growth and maturity during harvesting that depend on the ocean depth in the growth area. S. horneri can be utilized as a recyclable resource for a sustainable future both nutritionally and energetically; the upper part of the plant harvested at peak maturity for food, and entire aging plant harvested for biofuel before flowing out or after they have drifted ashore.

\section{Acknowledgements}

This study was partly supported by FWU Grant-in-Aid for Science Research in 2005 and 2006 from Fukuoka Women's University. The authors also thank Ms. Yumiko Matoba, Dr. Kosaku Noda and Dr. Takato Fujii for their help and Mr. Naoya Shinohara, Mr. Tatsuo Ushirokawa and Mr. Tuneki Akimoto of Fukuoka Fisheries \& Marine Technology Research Center for their help in collecting S. horneri.

\section{References}

[1] Armisen, R. (1995) World-Wide Use and Importance of Gracilaria. Journal of Applied Phycology, 7, 231-243. http://dx.doi.org/10.1007/BF00003998

[2] Noda, H., Amano, H., Arashiyama, K., Hashimoto, S. and Nisizawa, K. (1989) Antitumor Activity of Polysaccharides and Lipids from Marine Algae. Nippon Suisan Gakkaishi, 55, 1265-1271. http://dx.doi.org/10.2331/suisan.55.1265

[3] Preeprame, S., Hayashi, K., Lee, J.B., Sankawa, U. and Hayashi, T. (2001) A Novel Antivirally Active Fucan Derived from an Edible Brown Alga, Sargasumm horneri. Chemical and Pharmaceutical Bulletin, 49, 484-485. http://dx.doi.org/10.1248/cpb.49.484

[4] Church, F.C., Meade, J.B., Treanor, R.E. and Whinna, H.C. (1989) Antithrombin Activity of Fucoidan. Journal of Biological Chemistry, 254, 3618-3623.

[5] Athukorala, Y., Lee, K.W., Kimm, S.K. and Jeon, Y.J. (2007) Anticoagulant Activity of Marine Green and Brown Algae Collected from Jeju Island in Korea. Bioresource Technology, 98, 1711-1716. http://dx.doi.org/10.1016/j.biortech.2006.07.034

[6] Sakai, H., Uchiumi, T., Lee, J.B., Ohira, Y., Ohkura, J., Suzuki, T., Hayashi, T. and Takeguchi, N. (2004) Leukotrienes-Mediated Effects of Water Extracts from Sargasumm horneri, a Marine Brown Alga, on $\mathrm{Cl}^{-}$Absorption in Isolated Rat Colon. The Japanese Journal of Physiology, 54, 71-77. http://dx.doi.org/10.2170/jjphysiol.54.71

[7] Yamaguchi, M., Hachiya, S., Hiratuka, S. and Suzuki, T. (2001) Effect of Marine Algae Extract on Bone Calcification in the Femoral-Metaphyseal Tissues of Rats, Anabolic Effect of Sargassum horneri. Journal of Health Science, 47, 533-538. http://dx.doi.org/10.1248/jhs.47.533

[8] Nishide, E., Anzai, H. and Uchida, N. (1993) Effects of Alginates on the Ingestion and Excretion of Cholesterol in the Rat. Journal of Applied Phycology, 5, 207-211. http://dx.doi.org/10.1007/BF00004019

[9] Murakami, K., Yamaguchi, Y., Noda, K., Fujii, T., Shinohara, N., Ushirokawa, T., Katayama-S, Y. and Katayama, M. (2011) Seasonal Variation in the Chemical Composition of a Marine Brown Alga, Sargassum horneri (Turner) C. Agardh. Journal of Food Composition and Analysis, 24, 231-236. http://dx.doi.org/10.1016/j.jfca.2010.08.004

[10] Umezaki, T. (1984) ECOLOGICAL studies of Sargassum horneri (Turner) C. Agardh in Obama Bay, Japan Sea. Bulletin of the Japanese Society for the Science of Fish, 50, 1193-1200. http://dx.doi.org/10.2331/suisan.50.1193

[11] Yoshida, G., Amano, H., Arashima, K., Hashimoto, S. and Nisizawa, K. (2001) Growth and Maturation of Two Populations of Sargassum horneri (Fucales, Phaeophyta) in Hiroshima Bay, the Seto Inland Sea. Fisheries Science, 67, 1023-1029. http://dx.doi.org/10.1046/j.1444-2906.2001.00357.x

[12] Dawes, C.J. (1998) Chapter 4. Physiological Ecology. Marine Botany. 2nd Edition, John Wiley \& Sons, Inc., New York, 62-91

[13] Lobban, C.S., Harrison, P.J. and Duncan, M.J. (1985) The Physiological Ecology of Seaweeds. Cambridge University 
Press, New York, 4-110.

[14] Adams, J.M.M., Toop, T.A., Donnison, I.S. and Gallagher, J.A. (2011) Seasonal Variation in Laminariadigitata and Its Impact on Biochemical Conversion Routes to Biofuels. Bioresource Technology, 102, 9976-9984. http://dx.doi.org/10.1016/j.biortech.2011.08.032

[15] Yeon, J.-H., Lee, S.-E., Choi, W.Y., Kang, D.H., Lee, H.-Y. and Jung, K.-H. (2011) Repeated-Batch Operation of Surface-Aerated Fermentor for Bioethanol Production from the Hydrolysate of Seaweed Sargassumsagamianum. Journal of Microbiology and Biotechnology, 21, 323-331. http://dx.doi.org/10.4014/jmb.1008.08001

[16] Wargacki, A.J., Leonard, E., Win, M.N., Regitsky, D.D., Santos, C.N., Kim, P.B., Cooper, S.R., Raisner, R.M., Herman, A., Sivitz, A.B., Lakshmanaswamy, A., Kashiyama, Y., Baker, D. and Yoshikuni, Y. (2012) An Engineered Microbial Platform for Direct Biofuel Production from Brown Macroalgae. Science, 335, 308-313. http://dx.doi.org/10.1126/science.1214547

[17] AOAC (1995) Method 900.02, 934.01, 954.02, 955.04, 960.05. Official Methods of Analysis of AOAC International. 16th Edition, AOAC International, Virginia.

[18] Prosky, L., Asp, N.-G., Furda, I., DeVries, J.W., Schweizer, T.F. and Harland, B.F. (1985) Determination of Total Dietary Fibre in Foods and Food Product, Collaborative Study. Journal_Association of Official Analytical Chemists, 68, 677-679.

[19] Prosky, L., Asp, N.-G., Schweizer, T.F., DeVries, J.W. and Furda, I. (1988) Determination of Insoluble, Soluble, and Total Dietary Fibre in Foods and Food Products. Journal-Association of Official Analytical Chemists, 71, 1017.

[20] AOAC (1985) A14-43, A20. Official Methods of Analysis. 14th Edition, Association of Official Agricultural Chemists, Washington DC, 399.

[21] AOAC (1986) Changes in Methods. Journal-Association of Official Analytical Chemists, 69, 370.

[22] AOAC (1987) Changes in Methods. Journal-Association of Official Analytical Chemists, 70, 393. 